\title{
Variations in temperature and salinity of the surface water above the middle Okinawa Trough during the past $37 \mathrm{kyr}$
}

\author{
Hua $Y u^{a, b, ~}{ }^{*}$, Zhenxia Liu ${ }^{b}$, Serge Bernéc ${ }^{c}$ Guodong Jia ${ }^{d}$, Yingqian Xiong ${ }^{e}$, Gerald R. Dickens ${ }^{a}$, \\ Gangjian Wei ${ }^{d}$, Xuefa Shi ${ }^{b}$, J.Paul Liu ${ }^{f}$ and Fajin Chen ${ }^{d}$
}

\footnotetext{
a Department of Earth Sciences, Rice University, Houston, Texas, United States

${ }^{\mathrm{b}}$ First Institute of Oceanography, State Oceanic Administration, Qingdao, China

${ }^{c}$ IFREMER, Geosciences Marines, Plouzane, France

d Guangzhou Institute of Geochemistry, Chinese Academy of Sciences, Guangzhou, China

e Department of Geosciences, University of Houston, Houston, Texas, United States

f Department of Marine Earth and Atmospheric Sciences, North Carolina State University, Raleigh, North Carolina, United States
}

\section{*: Corresponding author : Hua Yu, Tel.: +1 281777 6780, email address : yuhua77@gmail.com}

\begin{abstract}
:
East China Sea (ECS) is an important climate modulator of East Asia. In the last glacial period, the global sea level, the path and strength of the Kuroshio Current experienced great changes; combined with the variable volume of fresh run-off input, they made the hydrographic situation in the ECS quite different from nowadays. Based on high-resolution alkenone-sea surface temperature (SST) and oxygen isotope composition of planktonic foraminifera Globigerinoides sacculifer we reconstructed paleo-sea surface salinity (SSS) of a long piston core DGKS9604 retrieved from the middle Okinawa Trough of the eastern ECS. The $\delta^{18} \mathrm{O}$ and SST records display significant variations with global ice volume. Synchrony of the millennial-scale climate events like YD and Heinrich events of core DGKS9604 to the ice core from the northern high latitudes, and the synchroneity of deglacial warming with the Bølling-Allerød warming suggests a strong coupling of the SST variations in the marginal Pacific Ocean to the climate of the North Atlantic, most likely through the Asian monsoon atmospheric circulation. The ECS documents lowest SST $\left(22^{\circ} \mathrm{C}\right)$ at $\sim 26 \mathrm{cal} \mathrm{kyr} \mathrm{BP}$ and $\sim 3^{\circ} \mathrm{C}$ SST difference between the full glaciation ( 26 to $19 \mathrm{cal} \mathrm{kyr} \mathrm{BP}$ ) and mid-to-late Holocene ( $6 \mathrm{cal}$ kyr BP-present). The overall long-term hydrographic variations in the middle Okinawa Trough are controlled by temporal and spatial variations in: (i) the intensity and position of the Kuroshio Current, (ii) intensity of the Asian summer monsoon and (iii) sea-level fluctuations coupled with ECS topography. Saline surface water dominated over the middle Okinawa Trough during early pre-glaciation (37 to $31 \mathrm{cal} \mathrm{kyr} \mathrm{BP}$ ), last deglaciation (19 to $11.6 \mathrm{cal} \mathrm{kyr} \mathrm{BP),} \mathrm{and} \mathrm{mid-to-late} \mathrm{Holocene} \mathrm{(6} \mathrm{cal} \mathrm{kyr} \mathrm{BP-present),} \mathrm{whilst} \mathrm{freshened}$ surface water prevailed during the late pre-glaciation (31 to 26 cal kyr BP), full glaciation (26 to $19 \mathrm{cal}$ kyr BP) and early Holocene (11.6 to 6 cal kyr BP).
\end{abstract}

Keywords: East China Sea; Okinawa Trough; Kuroshio Current; East Asian monsoon; Sea surface temperature; Sea surface salinity 


\section{Introduction}

Okinawa Trough, a primary focus of this study, is a long (1200 km), crescent-shaped, northeast trending back-arc basin located in the southeast portion of the East China Sea (ECS)

(Fig. 1). Connected with the open Pacific Ocean through seaways along the eastern margin, this area is sensitive to the global climate, sea level variations as well as local environmental changes. The current hydrographic situation of the Okinawa Trough are featured by the interaction between warm, saline Western Boundary Current, Kuroshio Current, from the east side and cold, and fresh coastal water supplied by larges rivers, specially the Changjiang (Yangtze) river, from the west side of China continents (Fig. 1) (e.g., Bryden et al., 1991; Hsueh, 2000; Tseng et al., 2000; Qiao et al., 2006; Itoh and Sugimoto, 2008; Andres et al., 2008; Nakano et al., 2008). However, the local hydrographic situation during past climate regimes remains an outstanding issue.

The present-day hydrography of the ECS must have been different during the last glacial period. Because eustatic sea level was 120 m lower in last glacial maximum (LGM) (e.g., Hanebuth et al., 2000), and the ECS continental shelf has a low morphological gradient (about 58"), most of sea floor on the continental shelf was exposed. Major rivers (e.g. Changjiang, Minjiang and Qiantangjiang) also advanced further seaward (Wellner and Bartek, 2003), likely debouching large volumes of water and sediment onto the outer continental shelf and into the

(Ujiié and Ujiié, 1999; Ujiié et al., 2003; Xu and Oda, 1999; Li et al., 2001; Ijiri et al., 2005). 
surface salinity (SSS) of the Okinawa Trough.

Previous discussions of these two parameters in this region have relied primarily on the assemblages of planktonic foraminifera, the $\delta^{18} \mathrm{O}$ of planktonic foraminifera, or both (Ujiié and Ujiié, 1999; Jian et al., 2000; Li et al., 2001; Ujiié et al., 2003). Because each proxy suffers from certain kinds of biases, such as growth seasonality, preservation, diagenetic degradation, calibrations, etc, a multiproxy reconstruction is justified (Mix et al., 2001; Bard, 2001). In this study, we generate high-resolution alkenone-sea surface temperature (SST) and $\delta^{18} \mathrm{O}$ records of Globigerinoides sacculifer for a long piston core from the western slope of the middle Okinawa Trough to examine changes in annual mean SST and SSS for the past $37 \mathrm{kyrs}$, and discuss the mechanisms controlling the local hydrographic variations in the ECS.

\section{Regional Setting}

\subsection{East China Sea}

The ECS is a large $\left(7.7 \times 10^{5} \mathrm{~km}^{2}\right)$ marginal sea in the western Pacific Ocean bordered by mainland China, the Korean Peninsula, and the islands of Taiwan, Kyushu and Ryukyu (Fig. 1). It extends about $1300 \mathrm{~km}$ from northeast to southwest, and about $740 \mathrm{~km}$ from east to west. The seafloor of the ECS can be conveniently divided into three general bathymetric regions: the continental shelf (generally $<120$ m water depth, mwd), the shelf break $(120-170 \mathrm{mwd})$ and the slopes and basin of Okinawa Trough (> $170 \mathrm{mwd}$ ). The continental shelf stretches up to $600 \mathrm{~km}$ across, making it the widest such feature in eastern Asia.

The Okinawa Trough has resulted from the collision of the Philippine and Eurasian plates 
80 (Sibuet et al., 1998). Although active today, rifting began from the middle to late Miocene ( 6

81 Ma; Shinjo et al., 1991). Consequently, the geometry of the Okinawa Trough has been fairly

82

83

84

85

86

87

88

89

90

91

92

93

94

95

96

97

98

99

100

similar over the late Pleistocene. At present, the Okinawa Trough deepens from the northern

( $\sim 900 \mathrm{mwd})$ to southern region ( $2700 \mathrm{mwd})$. Previous work indicates that a $>1 \mathrm{~km}$-thick sedimentary sequence since late Miocene drapes the trough (Ishibashi et al., 1995).

Several prominent rivers contribute large amounts of water and sediment to this marginal sea (Fig. 1). Changjiang River, the fourth longest in the world, discharges $\sim 920 \mathrm{~km}^{3} / \mathrm{yr}$ of water and $\sim 4.8 \times 10^{11} \mathrm{~kg} / \mathrm{yr}$ of sediment into the ECS (Milliman and Meade, 1983). Minjiang and Qiantangjiang Rivers discharge additional $\sim 94 \mathrm{~km}^{3} / \mathrm{yr}$ water and $\sim 14 \times 10^{9} \mathrm{~kg} / \mathrm{yr}$ sediment (Zhang, 1995). The fresh water input lowers SSS and changes hydrographic characteristics of water masses in the region, especially on the continental shelf (Beardsley et al., 1985). Given the broad modern continental shelf, coastal processes distribute and deposit most of the fluvial sediment around the river mouths and on the inner shelf; relatively small amounts of terrigenous sediment reach the Okinawa Trough at present.

Fluvial discharge into the ECS varies greatly with seasons because of the East Asian monsoon variation and the shift of intertropical convergence zone (ITCZ). In winter, ITCZ shifts southward, cold and dry Siberian (continental) air masses flow with a direction to the southeast from inner Asia to the ocean. In summer, ITCZ shifts northward, warm and humid air masses flow in northwest direction from the Pacific and Indian Oceans. This leads to enhanced precipitation to the Chinese mainland in summer season. Consequently, approximately $70 \%$ of the annual discharge of the Changjiang River occurs between May and October (Chen et al., 
101

102

103

104

105

106

107

108

109

110

111

112

113

114

115

116

117

118

119

120

121

2001).

\subsection{Kuroshio Current}

The Kuroshio Current is the major western boundary current in the North Pacific (Fig. 1).

The modern Kuroshio Current generally flows northeast above the Okinawa Trough (Fig. 1) as a water mass up to $100 \mathrm{~km}$ wide and 800 to $1000 \mathrm{~m}$ deep. This current originates near the Equator and enters the ECS from the Philippine Sea through the Suao-Yonaguni Depression. It returns to the North Pacific through Tokara Strait and merges with the North Pacific Current at roughly $37^{\circ}$ $\mathrm{N}$ off the Japan coast. The velocity of the current varies both regionally and seasonally, ranging from 45 to $150 \mathrm{~cm} / \mathrm{s}$ (Qin et al., 1987). The flux of the Kuroshio Current also changes over time, particularly with the El Niño Southern Oscillation. Strong transport occurs during La Niña years when trade winds intensify, and weak transport occurs during El Niño years (Wyrtki, 1975; Qiu and Lukas, 1996). Typical water flux ranges from 21 to $33 \mathrm{~Sv}$ (Sverdrup, $1 \mathrm{~Sv}=10^{6} \mathrm{~m}^{3} / \mathrm{s}$ ) (Roemmich and McCallister, 1989; Johns et al., 2001).

The temperature and salinity on the ECS continental shelf and slope are controlled by the mixing of the continental run-off and the Kuroshio Current waters, resulting in a gradient that rises from the inner shelf to the shelf edge (Zhang et al., 1990).

\section{Materials and methods}

\subsection{Sediment core}

Piston core DGKS9604 was recovered by $R / V L$ 'ATALANTE from the middle Okinawa 
122 Trough in 1996 during the joint Chinese-French DONGHAI cruise. The core site was chosen in

123 this study because seismic profiles showed thick packages of sediment with little evidence for

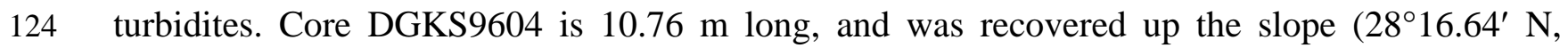
$125127^{\circ} 01.43^{\prime}$ E) at 766 mwd (Fig. 1). It comprises homogeneous gray clayey silt, but has no ash 126 layers (Fig. 2). The core was cut into 1 m-long sections (excepting the short bottoms), then split, 127 described and sampled every $2 \mathrm{~cm}$ over the upper $100 \mathrm{~cm}$, and every $4 \mathrm{~cm}$ below.

\subsection{Laboratory analyses}

Bulk sediment samples from core DGKS9604 were split into several aliquots for various analyses. Planktonic foraminifera shells were extracted from a set of sediment aliquots and analyzed for their isotopic compositions. Bulk sediment samples were washed through a $63 \mu \mathrm{m}$

133 sieve and dried in an oven at $60{ }^{\circ} \mathrm{C}$. Between 17 and $37 \mathrm{mg}$ of planktonic foraminifera

134 Neogloboquadrina dutertrei from 10 intervals and one planktonic foraminiferas mixture from the 135 very bottom were picked for radiocarbon analyses at the National Ocean Sciences Accelerator Mass Spectrometry facility, Woods Hole Oceanographic Institution (Table 1). core $(0-100 \mathrm{~cm}), 4 \mathrm{~cm}$ through the middle interval of the core $(100-600 \mathrm{~cm})$, and $12 \mathrm{~cm}$ through the basal section (600- $1076 \mathrm{~cm}$ ). Between 15 and 20 specimens of $G$. sacculifer (without the 140 sac-like final chamber) in the 300 350 $\mu \mathrm{m}$ size fractions were collected under microscope. All 141 tests were washed with ethanol in an ultrasonic bath, dried at $60^{\circ} \mathrm{C}$, and measured at the 142 Laboratory of Isotope Geochronology and Geochemistry, Guangzhou Institute of Geochemistry, 
143 Chinese Academy of Sciences using a GV IsoPrime stable isotope mass spectrometer. Results are 144 presented using standard delta notation (\%o) relative to Vienna Pee Dee Belemnite (VPDB)

145 (Table 2). The analytical precision is better than $\pm 0.08 \%$ o for oxygen isotopes.

146 A third set of aliquots was stored in a cold room at $-4{ }^{\circ} \mathrm{C}$ and subsequently processed for 147 alkenone measurements. Following procedures of Villanueva et al. (1997), freeze-dried samples 148 were homogenized with an agate mortar and pestle ( 4 g), spiked with an internal standard of 149 n-hexatriacontane, and placed in an ultrasonic bath with dichloromethane. Extracts were then 150 hydrolyzed with $6 \%$ potassium hydroxide in methanol to remove terrigenous wax esters.

151 Non-acidic compounds were recovered by extraction with $n$-hexane and elution by 8:2 152 dichloromethane-n-hexane in columns packed with $2 \mathrm{~g}$ silica. The collected solvents were 153 evaporated under a nitrogen stream and re-dissolved with $20 \mu \mathrm{l} n$-hexane. They were then 154 analyzed using an HP 6890 gas chromatograph equipped with a cold on-column injector system, 155 a fused silica capillary column, and a flame ionization detector (FID). Helium, at a flow rate of $1561.6 \mathrm{ml} / \mathrm{min}$, was used as carrier gas. Oven temperature was programmed at $100{ }^{\circ} \mathrm{C}$ for 3 minutes 157 (min), raised to $240{ }^{\circ} \mathrm{C}$ at a rate of $10^{\circ} \mathrm{C} / \mathrm{min}$, raised to $295^{\circ} \mathrm{C}$ at a rate of $2.5^{\circ} \mathrm{C} / \mathrm{min}$ and then 158 kept isothermal at $295{ }^{\circ} \mathrm{C}$ for $50 \mathrm{~min}$. Alkenones were identified based on their retention times 159 and their concentrations were determined by comparing FID responses to known internal 160 standard concentrations (Fig. 3).

\subsection{Chronology}

For core DGKS9604, radiocarbon ages less than 20 kyr were converted to calendar ages 
164 (cal kyr BP) using the CALIB 4.4 program (Stuiver et al., 1998). Radiocarbon ages older than 20

165 kyr were converted to calendar ages with the 'Fairbanks0805' calibration curve (Fairbanks et al., 166 2005) (Table 1). The age model for core DGKS9604 was initially derived by linear interpolation 167 between 10 of the 11 corrected radiocarbon ages (Table 1; Fig. 2). These datum occur in 168 reasonable stratigraphic order, and indicate deposition over the last 37 kyrs. The radiocarbon age 169 from 520-522 cm below the seafloor (cmbsf) is too young compared to surrounding intervals, 170 suggesting sediment disturbance by bioturbation or mass wasting. Although turbidites were not 171 observed in this core, small turbidite layers have been found in other cores from the Okinawa 172 Trough ( $\mathrm{Li}$ et al., 2003). In any case, this age has been ignored in the construction of the age 173 model.

174 On the basis of this stratigraphy, apparent sedimentation rates generally decrease from late 175 glaciation toward the present (Fig. 2). In core DGKS9604 the sediment accumulation rates vary 176 from an average of $\sim 40 \mathrm{~cm} / \mathrm{kyr}$ during the late glaciation to an average of $\sim 20 \mathrm{~cm} / \mathrm{kyr}$ during the 177 last deglaciation and the Holocene. The age resolution for successive samples in this core is 178 about 100-300 yrs, significantly higher than those in cores from previous studies of the middle 179 Okinawa Trough (Ujiié and Ujiié, 1999; Ujiié et al., 2003).

\subsection{SST reconstruction}

Two long-chain $\mathrm{C}_{37}$ methyl alkenones were found in core DGKS9604: $\mathrm{C}_{37: 2 \mathrm{Me}}$ (containing 2 
186

187

188

189

190

191

192

193

194

195

196

197

198

199

200

201

202

203

204

205

Brassell et al., 1986; Prahl and Wakeham, 1987; Müller et al., 1998). A commonly used expression for the $\mathrm{C}_{37}$ alkenone abundance is the degree of ketone unsaturation $\left(U_{37}^{k}\right)$, calculated as:

$$
U_{37}^{k}=\left(C_{37: 2 \mathrm{Me}}-C_{37: 4 M e}\right) /\left(C_{37: 2 \mathrm{Me}}+C_{37: 3 \mathrm{Me}}+C_{37: 4 \mathrm{Me}}\right)
$$

Because $\mathrm{C}_{37: 4 \mathrm{Me}}$ is generally produced at low temperatures and accounts for only small part of the total ketone concentration, this index (Eqn. 1) is often simplified to (Prahl and Wakeham, 1987):

$$
U_{37}^{k^{\prime}}=C_{37: 2 M e} /\left(C_{37: 2 M e}+C_{37: 3 M e}\right) .
$$

A linear relationship between $U_{37}^{K^{\prime}}$ and SST is apparent for most of the modern ocean between $60^{\circ} \mathrm{N}$ and $60^{\circ} \mathrm{S}$ where temperatures range from $0{ }^{\circ} \mathrm{C}$ to $29^{\circ} \mathrm{C}$ (Prahl and Wakeham, 1987; Müller et al., 1998). A global core-top calibration for this relationship is (Müller et al., 1998):

$$
S S T=\left(U_{37}^{k^{\prime}}-0.044\right) / 0.033
$$

We have applied equations (2) and (3) to alkenone determinations of samples from core DGKS9604 (Table 2). The core-top (0-1 cmbsf) for core DGKS9604 gives a SST of $26.2{ }^{\circ} \mathrm{C}$, which compares favorably to the present-day annual mean SST at this location of $25.7^{\circ} \mathrm{C}$ within the error estimate (Table 3). The replicate measurements of alkenone show that uncertainties ( \pm $1 \sigma$ ) for $U_{37}^{K^{\prime}}$ are \pm 0.006 , thus, $\pm 0.2^{\circ} \mathrm{C}$ for SST.

\subsection{SSS reconstruction}

Planktonic foraminiferal oxygen isotope records can be used to reconstruct past SSS if (1) 
206 the SST component of the signal can be "removed", (2) global salinity variations resulted from 207 changes in ice volume can be "subtracted", and (3) the oxygen isotope composition of ambient water co-varied with salinity predictably (Schmidt et al., 2006; Weldeab et al., 2006; Toledo et al., 209 2007). For $G$. Sacculifer, water temperature $\left(T\right.$ in ${ }^{\circ} \mathrm{C}$ ) relates to $\delta^{18} \mathrm{O}$ as follows (Erez and Luz, 210 1983):

$$
T=17.0-4.52\left(\delta^{18} O_{c}-\delta^{18} O_{w}\right)+0.03\left(\delta^{18} O_{c}-\delta^{18} O_{w}\right)^{2},
$$
where the subscripts $\mathrm{c}$ and $\mathrm{w}$ refer to test calcite and seawater, respectively.

214 last four glacial-interglacial cycles. This record suggests a $1.05 \%$ o decrease in mean $\delta^{18} \mathrm{O}_{\mathrm{w}}$ from 215 the LGM to the Holocene. Oba (1990) has shown a linear relationship between SSS and $\delta^{18} \mathrm{O}_{\mathrm{w}}$ 216 for the region of the ECS influenced by the Kuroshio Current (Eqn. 5, Fig. 4):

$$
\delta^{18} \mathrm{O}_{\mathrm{w}}=0.203 \text { SSS }-6.76 \text {. }
$$

Assuming the relationship between SSS and $\delta^{18} \mathrm{O}_{\mathrm{w}}$ has been constant through the last

219 glacial-interglacial cycle, Equations 4 and 5 enable fairly precise SSS records to be calculated 220 from alkenone SST and foraminiferal $\delta^{18} \mathrm{O}_{\mathrm{c}}$ records by subtracting the global salinity signal.

\section{Results}

\subsection{Sea surface temperature trends}


227 glacial-interglacial cycle, an observation made at many locations.

228 The basal part of core DGKS9604 shows small fluctuations in the SSTs that seem to 229 stabilize around $23.5^{\circ} \mathrm{C}$ from 37 to $31 \mathrm{cal} \mathrm{kyr} \mathrm{BP}$ (calibrated thousands of years before present, 230 i.e., $1950 \mathrm{AD}$ ), which we refer as the "early pre- glaciation” (Fig. 5E). A large cooling peaked 231 around 30.5 cal kyr BP appears contemporaneous with the North Atlantic Heinrich event 3 (H3); 232 the $\delta^{18} \mathrm{O}$ shifted $1 \%$ heavier and the SSTs dropped $1-2{ }^{\circ} \mathrm{C}$ (Fig. 5B, D, E). Then the SST 233 reversed gradually, culminating in peak warmth to $\sim 24^{\circ} \mathrm{C}$ at $27 \mathrm{cal} \mathrm{kyr}$ BP. SSTs subsequently 234 dropped, reaching minimum temperature over our study interval at $\sim 26 \mathrm{cal}$ kyr BP about $22^{\circ} \mathrm{C}$. 235 Following the minimum SSTs, the surface water above the middle Okinawa Trough sustained 236 cold through the full glacial time interval (26-19 cal kyr BP). Comparing with the late Holocene 237 the SSTs over study site dropped $\sim 3^{\circ} \mathrm{C}$ in the LGM (Fig. 5E). This long-term glacial duration 238 possibly suggest the lowest glacial sea level has reached at ca.26 cal kyr BP in the ECS, which is 239 consisted with records from Barbados Island (Peltier and Fairbanks, 2006). Whilst this long-term 240 cold interval was culminated by a large cooling event near $21.5 \mathrm{cal}$ kyr BP, coeval with H2 in 241 North Atlantic (Fig. 5E). The surface water started to warm slowly during the first deglacial 242 phase and was terminated by a cooling event happened at ca. 17-15.4 cal kyr BP, which 243 documented $\sim 1^{\circ} \mathrm{C}$ SST drop and corresponded to $\mathrm{H} 1$ event recorded in Greenland ice cores (Fig. 244 5E). Contemporaneous with the Bølling/Allerød warming recorded in high latitudes of the 245 northern hemisphere the SSTs over our study site, in phase with the G.sacculifer $\delta^{18} \mathrm{O}$ records, 246 began to increase rapidly at ca.14.7 cal kyr BP, synchronous with the melt water pulse - 1A 247 (MWP-1A) (Fig. 5A, E), marking the second half of the last deglaciation. It was terminated by a 
248 major cooling event, peaked around 11.6 cal kyr BP, synchronous with the North Atlantic YD

249 cold event (Fig. 5). In the early Holocene, from 11.6 to 8.5 cal kyr BP the SSTs over site 250 DGKS9604 increased abruptly, accomplishing the ultimate recovery from the YD cold reversion.

251 A cooling event around 8.2 cal kyr BP was documented both in SSTs and G.sacculifer $\delta^{18} \mathrm{O}$ 252 records, which has been discussed in detail by Yu et al. (2007). In mid and late Holocene since 6 cal kyr BP, the SSTs stabilized at $26^{\circ} \mathrm{C}$.

\subsection{Sea surface salinity trends}

The accuracy of the SSS records warrants commentary because, unlike other studies using

Mg/Ca (e.g., Schmidt et al., 2006; Weldeab et al., 2006), the SST and $\delta^{18} \mathrm{O}_{\mathrm{c}}$ records have been determined on different phases made by different organisms. In particular, coccolithophorids and G. sacculifer have different growing seasons in ECS. Sediment trap studies in the eastern ECS demonstrate that the flux of coccoliths to the sea floor is high throughout the year with the exception of summer months (Tanaka, 2003), whereas the flux of G. sacculifer shells is high throughout the year with the exception of winter months (Yamasaki and Oda, 2003; Xu et al.,

263 2005). However, both organisms grow prosperously in spring and fall, when most surface water

264 properties, including SST and SSS, approach annual averages (Table 3). Therefore, $U_{37}^{K^{\prime}}$-derived

265 SSTs could be a good candidate to be used to obtain accurate average SSSs in the region.

266 What's more, reconstructed SSS for core DGKS9604 averaging at 34.4\%o during the Late 267 Holocene (0-6 cal kyr BP) matches very well with instrument measured present-day annual 268 average SSS of $34.51 \pm 0.23 \%$ at the core site (Table 3). 

is partially caused by the point-to-point calculation of individual $\delta^{18} \mathrm{O}$ and alkenone SST values. However this does not preclude making general comments about the trend of these oscillations by soothing the record (Fig. 5F). During the early pre-glacial period, from 37 to 31 cal kyr BP the SSSs stabilized at ca. 34\%o in core DGKS9604. Following the high early pre-glacial SSS, a long-term low SSS excursion peaked around 28 cal kyr BP with SSS dropping up to 5\%. This seems synchronous with the Dansgaard-Oeschger (D-O) cycle 3 and/or 4 (Dansgaard et al., 1993)

(Fig. 5B, F). A decreasing SSS trend persisted from 26 to 19 cal kyr BP throughout the full glaciation (Fig. 5F). Over the early last deglaciation, from 19 to 14.7 cal kyr BP, an obvious increasing trend was observed in the core, comparing with a clear decreasing trend between 14.7 and 11.6 cal kyr BP. In early Holocene, from 11.6 to 6 cal kyr BP, a prominent decrease trend in salinity was documented. SSSs dropped up to 3-4\%o during this time interval. In Mid-to-late Holocene (6 cal kyr BP to present) the SSSs increased to stabilize at 34.4\%o over site core DGKS9604.

\section{Discussion}

The accuracy of the reconstructed paleo-SSS records in this study suffered from 1) 
and 8200 cooling event here. We pay more attention on long-term hydrographic evolution in this

291

292

293

294

295

296

297

298

299

300

301

302

303

304

305

306

307

308

309

310

paper.

\subsection{Pre-glaciation}

During early pre-glaciation, from 37 to 31 cal kyr BP, the average SSS for core DGKS964 was almost as the same as the modern situation (Fig. 5F). As to temperature the SSTs in the middle Okinawa Trough at that time were about 23 to $24{ }^{\circ} \mathrm{C}$ (Fig. 5E), just a little colder than present-day. Local paleoclimate studies based on different archives indicated a very humid climate in early pre-glaciation (Shi and Yu, 2003); the precipitation brought by the Asian summer monsoon in southeast China was as high as that of late Holocene as suggested by the speleotheme $\delta^{18} \mathrm{O}$ record (Yuan et al., 2004, Fig. 5C). Large transgressions occurred in the ECS, where the sea level was only 2.5-12.25 m lower than the present-day sea level, much lower than the global estimation of 20-40 m (Chappell et al., 1996) due to local tectonic subsidence (Yang et al., 2004; Zhao et al., 2008). In our study site a tremendous high sedimentation rate, $\sim 70 \mathrm{~cm} / \mathrm{kyr}$ occurred during 33 to 31 cal kyr BP in core DGKS9604 (Fig. 2), which could correspond to maximum transgression in the ECS. This high stand could partially facilitate large volume of warm and saline Kuroshio Current penetrated through Suao-Yonaguni Depression in our study area and kept this slight saline surface water high persisting over the middle Okinawa Trough for about 7 kyrs. Additionally high Asian summer monsoon would make the North Equatorial

Current (NEC) bifurcation position shift southward (Qiu and Lukas, 1996), and the Kuroshio Current extended deeper (Qu and Lukas, 2003), both resulting in a significant amount of warm 
311 and salty equatorial water transported toward the pole.

However during the late pre-glaciation the timing of SST, $\delta^{18} \mathrm{O}$ and SSS between core

313 DGKS9604 and north Greenland ice core was quite complicated. Most notably, at the

314 termination of H3 SST oscillated with high frequencies, but a consistent and obvious decreasing

315 salinity trend was documented in our records, which centered around 28-29 cal kyr BP (Fig. 5E,

316 F). This possibly indicated the influence of strong Asian summer monsoon in response to the

317 warm stadial period D-O 3 and/or 4 in North Atlantic (Fig. 5B, C). Large precipitation brought

318 by the Asian summer monsoon could lead this low SSS anomaly. However more high-resolution

319 paleoclimate records of this time interval are needed to reveal the mechanism of this SSS

320 excursion.

321

$322 \quad 5.2$ Full glacial period

323 During the full glacial interval (26-19 cal kyr BP) the SSTs over study site were as low as $32422^{\circ} \mathrm{C}$, dropped $\sim 3^{\circ} \mathrm{C}$ comparing with the late Holocene (Fig. 5E). This is consistent with records 325 from other cores in this area (Xiong and Liu, 2004; Ijiri et al., 2005; Sun et al., 2005; Zhou et al., 326 2007). Although there are some high SSS bumps, a decreasing trend in SSS curve was observed 327 during this period (Fig. 5F). This could be explained by the more easterly position of the river drainage systems on the exposed shelf and/or reduced Kuroshio Current intensity. A significant

329 sea-level fall of 120 m during the LGM (Chappell et al., 1996; Hanebuth et al., 2008) have 
332 advanced seaward hundreds of kilometers during the low stand. Thus the position of the river

333 plume was more proximal to the core site (Wellner and Bartek, 2003). Therefore a larger volume

334 of fresh water would have entered our study sites although less precipitation and less absolute

335 discharge of the Yangtze River into the ECS was probably deduced by decreased Asian summer

336 monsoon as implied by the Chinese speleotheme records (An et al., 1991; Wang and Sun, 1994;

337 Yuan et al., 2004). The enhanced fresh run-off at this time has been reported in the northern

338 Okinawa Trough (Xu et al., 1999; Ijiri et al., 2005) as well as in the nearby core site DGKS9603

339 from geochemical evidences (Xiong and Liu, 2004). Additionally the path and strength of the

340 Kuroshio Current experienced great changes during this period (Ujiié and Ujiié, 1999; Ujiié et al.,

341 2003; Xu and Oda, 1999; Li et al., 2001; Ijiri et al., 2005). This Current may have been reduced

342 greatly in intensity ((Xu and Oda, 1999; Ijiri et al., 2005) or completely prevented from entering

343 the ECS by a land bridge connecting the central and southern Ryukyu Arc with Taiwan. It could

344 turned eastward south of the Ryukyu Arc, but not flowing above the Okinawa Trough during the

345 LGM (Ujiié and Ujiié, 1999, Ujiié 2003; Jian et al., 2000; Li et al., 2001). Reduced Kuroshio

346 Current intensity or complete shift-out of such current would be another important factor

347 resulting in this low salinity during full glaciation.

\section{$349 \quad 5.3$ Last deglaciation}

350 Synchronously with the LGM termination (19, $000 \pm 250$ years, Yokoyama et al., 2000) the

351 SSS over site DGK9604 reveals a clear increasing trend, especially between 19 and 14.7 cal kyr

352 BP (Fig. 5F). The association of cold and extreme salty sea surface water in the early last 
deglaciation could be explained by the coupling variations in the Kuroshio Current and the Asian summer monsoon intensity. At the termination of LGM, continental ice volume decreased rapidly by about $10 \%$, which resulted in a rapid sea level rise of 10-15 m, namely 19-kyr MWP (Fig. 5A) (Yokoyama et al., 2000; Clark et al., 2004; Hanebuth et al., 2008). This could enhance the throughflow of salty Kuroshio Current in the middle Okinawa Trough due to the disappearance of the topographic high blocks at LGM low stand. Whilst at this time interval the winter monsoon was still in very strong intensity and summer monsoon was weakened further (Fig. 5C), this more arid climate could boost the remarkably saline hydrographic condition at the first phase of last deglaciation over study area.

Synchronous with Bølling-Allerød warming in the North Atlantic at 14.7 cal kyr BP both $U_{37}^{K^{\prime}}$-SST and $\delta^{18} \mathrm{O}$ show abrupt warming of surface water in the trough area, corresponding to a quick reversal of strong Asian summer monsoon (Fig. 5B, C, D, E). This agrees with many observations in the East Asian marginal seas like the South China Sea (Review see Kiefer and Kienast, 2005). It suggests a close coupling of the SST variations to the climate of the North Atlantic through the atmospheric circulation. Although the absolute SSS values were still high, there is a clear trend toward lower salinity over the late last deglaciation, between 14.7 to 11.6 cal kyr BP (Fig. 5F). By comparing with the Asian summer monsoon records (Fig. 5C) this decreasing salinity could be caused by the gradually increased precipitation brought by the enhanced summer monsoon.

It might be tempting to think that the excessively high absolute SSS value during the whole last deglaciation, especially from 16 to $11.6 \mathrm{cal} \mathrm{kyr} \mathrm{BP}$, is an artifact of outstandingly warm 
374 alkenone SST estimates (Fig. 6A). However other temperature proxies revealed similar warm 375 situation in the Okinawa Trough in the second half of last deglaciation (Fig. 6B, C). A nearby 376 core A7 $\left(126^{\circ} 58.7^{\prime} \mathrm{E}, 2^{\circ} 49.2^{\prime} \mathrm{N}\right)$ show high SSTs around $25^{\circ} \mathrm{C}$ based on $\mathrm{Mg} / \mathrm{Ca}$ ratios of 377 foraminifera G. ruber (Fig. 6B) (Sun et al., 2005). Although not as well resolved as $U_{37}^{K^{\prime}}$ and $378 \mathrm{Mg} / \mathrm{Ca}$ - SST records, SST reconstructions based on planktonic foraminiferal assemblage from 379 core DGKS9603 also show high temperature around $26^{\circ} \mathrm{C}$ in cold season and $28^{\circ} \mathrm{C}$ in warm 380 season during the late last deglaciation (Fig. 6C) (Li et al., 2001). Those multiple proxies 381 corroborate the outstanding high sea surface temperature, therefore, high surface salinity during 382 the last deglaciation, indicating profound changes in oceanic conditions. We argue that the warming in the northern high latitudes, northward displacement of the ITCZ and strengthening of 384 northeast trade winds during more La Niña-like last deglacial conditions induced an 385 intensification of heat and salinity transport associated with the Kuroshio Current (Koutavas et 386 al., 2002). Both high SST and SSS values occurred at 16 cal kyr BP, possibly suggesting the restoration of high intensity Kuroshio Current in the middle Okinawa Trough could achieve fulfillment at 16 cal kyr BP after LGM. Since then warm and saline surface water dominated over the trough area (Fig. 5E,F). This point is also supported by paleoceanographic evidences from core DGKS9603 (Li et al., 2001). Heat and salt release from the Kuroshio Current may Archipelago. 

observed over the middle Okinawa Trough (Fig. 5F). One plausible explanation for this long-term decrease in SSS by 3-4\% is supreme precipitation associated with high intensity in Asian summer monsoon at this interval, which is clearly evidenced by oxygen isotope of stalagmite formations in caves from southeast China (Fig. 5C) (Wang et al., 2001; Yuan et al., associated with strong El Niño activities in early Holocene, as documented in Peruvian sea

402

403

404 405 406 407 408 409 410 411 412 413 414 415

(Carré et al., 2005; Wang and Hu, 2006).

Followed this long-term salinity low, the SSS increased gradually from 6 cal kyr BP. It is well corresponding to the colder and dryer climate in the mid-to-late Holocene. Southward shift of ITCZ and weakened Asian summer monsoon could be the major factors inducing such climate, therefore surface oceanography in our study area (Wanner et al., 2008).

\section{Conclusion}

Although there are some uncertainties inherent with the reconstructed paleo-SSS records in this study, combination of SST, SSS and other evidences allow some key conclusions to be drawn about the long-term hydrographic variations in the middle Okinawa Trough.

(1) The SST variation pattern over long sedimentation sequence in the middle Okinawa Trough show strong correlation with climate records from high latitude of the northern hemisphere. It suggested a close coupling of the SST variations in the marginal Pacific Ocean to the climate of the North Atlantic through the atmospheric circulation, most likely the Asian 
monsoon system.

(2) Persistent and pronounced cooling prevailed in the middle Okinawa Trough for the time interval from 26 to 19 cal kyr BP. It possibly indicated the lowest sea level have already taken

419 placed at 26 cal kyr BP in the ECS, which is suggested by Peltier and Fairbanks (2006) at the 420 island of Barbados.

(3) The SST difference between the full glaciation and late Holocene is $\sim 3^{\circ} \mathrm{C}$ in the ECS.

(4) The SSS was low at the full glaciation, which could be contributed to the proximal position of the continental river plume and reduced Kuroshio Current intensity.

(5) The SSS started to increase at 19 cal kyr BP, synchronous with the 19-kyr sea level rise. The pulse-like sea level rise might have played a crucial role in the restoration of high intensity Kuroshio Current in the middle Okinawa Trough. The fulfillment of the restoration of this current could achieve on 16 cal kyr BP, when warm and saline surface water dominated the middle Okinawa Trough.

(6) The outstanding decreasing salinity trend since the late deglaciation ( 14.7 cal kyr BP), especially persisted and eminent low SSS in the early Holocene, from 11.6 to 6 cal kyr BP, indicated strong controlling of the Asian summer monsoon on the hydrographic situation over area circum-continental slope. This observation is first reported in the middle Okinawa Trough 433 so far.

(7) Overall the long-term hydrographic variations in the middle Okinawa Trough are mainly driven by an interaction of the intensity and position of the Kuroshio Current, intensity of the Asian summer monsoon and sea level fluctuations coupled with topography. 


\section{Acknowledgements}

We are grateful to the crew of DONGHAI cruise of R/V L'Atalante in the ECS in 1996 for their support in sampling core DGKS9604. We thank Glen Snyder and Micah Nicolo for helpful

441 remarks and language corrections. We also are indebted to two anonymous reviewers for their

442 constructive comments on this paper. This work was funded by joint Chinese-French project supported by the NSFC (Grant No. 40421150011), MOST (Grant No. 2003cb716706) and NSF, 444 China (Grant No. 40431002). The DONGHAI cruise was funded by IFREMER.

\section{References}

447

An, Z., Kukla, G.J., Porter, S.C., Xiao, J., 1991. Magnetic susceptibility evidence of monsoon variation of the Loess Plateau of Central China during the last 130,000 years. Quaternary Research 36, 29-36.

Andres, M., Park, J.H., Winibush, M., Zhu, X., Chang, K., Ichikawa, H., 2008. Study of the Kuroshio/Ryukyu Current System Based on Satellite-Altimeter and in situ measurements. Journal of Oceanography 64 (6), 937-950.

Bard, E., 2001. Comparison of alkenone estimates with other paleotemperature proxies. Geochemistry, Geophysics, Geosystems, doi: 2000GC000050.

Beardsley, R.C., Limeburner, R., Yu, H., Cannon, G.A., 1985. Discharge of the Changjiang (Yangtze River) into the East China Sea. Continental Shelf Research 4, 57-76.

Brassell, S.C., Brereton, R.G., Eglinton, G., Grimalt, J., Liebezeit, G., Marlowe, I.T., Pflaumann, 
U., Broecker, W.S, 1986. Oxygen isotope constraints on surface ocean temperatures. Quaternary Research 26, 121-134.

460

461

462

463

464

465

466

467

468

469

470

471

472

473

474

475

476

477

478

Bryden, H.L., Roemmich, D.R., Church, J.A., 1991. Ocean heat transport across $24^{\circ} \mathrm{N}$ in the Pacific. Deep-Sea Research 38, 297-324.

Carré, M., Bentaleb, I., Fontugne, M., Lavallée, D., 2005. Strong El Niño events during the early Holocene: stable isotope evidence from Peruvian sea shells. The Holocene 15, 42-47.

Chappell, J., Omura, A., Esat, T., McCulloch, M., Pandolfi, J., Ota, Y., Pillans, B., 1996.

Reconciliation of late Quaternary sea levels derived from coral terraces at Huon Peninsula with deep sea oxygen isotope records. Earth Planet Science Letter 141, 227-236.

Chen, X., Zong, Y., Zhang, E., Xu, J., Li, S., 2001. Human impacts on the Changjiang (Yangtze) River basin, China, with special reference to the impacts on the dry season water discharges into the sea. Geomorphology 41, 111-123.

Clark, P.U., McCabe, A.M., Mix, A.C., Weaver, A.J., 2004. Rapid rise of sea level 19,000 years ago and its global implications. Science 304, 1141-1144.

Dansgaard, W., Johnson, S.J., Clausen, H.B., Dahl-Jensen, D., Gundestrup, N.S., Hammer, C.U., Hvidberg, C.S., Steffensen, J.P., Sveinbjörnsdottir, A.E., Jouzel, J., Bond, G., 1993. Evidence for general instability of past climate from a 250 kyr ice-core record. Nature 364, 218-220.

Dykoski, C.A., Edwards, R.L. Cheng, H., Yuan, D., Cai, Y., Zhang, M., Lin, Y., Qing, J., An, Z., Revenaugh, J., 2005. A high-resolution, absolute-dated Holocene and deglacial Asian monsoon record from Dongge Cave, China. Earth and planetary science letter 233, 71-86. 
479 Erez, J., Luz, B., 1983. Experimental paleotemperature equation for planktonic foraminifera. Geochimica et Cosmochimica Acta 47, 1025-1031.

481 Fairbanks R.G., Mortlock R.A., Chiu T.C., Cao L., Kaplan A., Guilderson T.P., Fairbanks T.W., Bloom A.L., Grootes P.M., Nadeau M.J., 2005. Radiocarbon calibration curve spanning 0 to 50,000 years BP based on paired ${ }^{230} \mathrm{Th} /{ }^{234} \mathrm{U} /{ }^{238} \mathrm{U}$ and ${ }^{14} \mathrm{C}$ dates on pristine corals.

Grootes, P. M., Stuiver, M., White, J. W. C., Johnsen, S. J., Jouzel, J., 1993. Comparison of 486 Quaternary Science Reviews 24, 1781-1796.

Hanebuth T., Stattegger K., Grootes P.M., 2000. Rapid flooding of the Sunda Shelf: a late-glacial sea-level record. Science 288, 1033-1035.

Hanebuth, T.J.J., Stattegger, K., Bojanowski, A., 2008. Termination of the Last Glacial Maximum sea-level lowstand: The Sunda-Shelf data revisited. Global and Planetary Change doi: 10.1016/j.gloplacha.2008.03.011.

Hsueh Y., 2000. The Kuroshio in the East China Sea. Journal of Marine Systems 24, 131-139. changes in the northern area of the East China Sea during the past 42,000 years. Palaeoceanography, Palaeoclimatology, Palaeoecology 219, 239-261. geochemistry of hydrothermal fluids from the Mid-Okinawa Trough back arc basin, southwest of Japan. Chemical Geology 123, 1-15. 
Itoh, S., Sugimoto, T., 2008. Current variability of the Kuroshio near the separation point from the western boundary. Journal of Geophysics Research 113, C11020, doi: 10.1029/2007JC004682.

Jian, Z., Wang, P., Saito, Y., Wang, L., Pflaumann, U., Oba, T., Cheng, X., 2000. Holocene variability of the Kuroshio Current in the Okinawa Trough, northwestern Pacific Ocean. Earth and Planetary Science Letters 184, 305-319.

Johns, W.E., Lee, T.N., Zhang, D., Zantopp, R., 2001. The Kuroshio east of Taiwan: moored transport observations from the WOCE PCM-1 array. Journal of Physical Oceanography 31, 1031-1053.

Kiefer, T., Kienast, M., 2005. Patterns of deglacial warming in the Pacific Ocean: a review with emphasis on the time interval of Heinrich event 1. Quaternary Science Reviews 24, 1063-1081.

Koutavas, A., Lynch-Stieglitz, J., Marchitto, T.M., Sachs, J.P., 2002. El Niño-like pattern in Ice Age tropical Pacific sea surface temperature. Science 297, 226-230.

Li, J., Gao, S., Sun, Y., Zeng, Z., 2003. Grain-size variation of terrigenous sediment sequences in the South Okinawa Trough (in Chinese with English abstract). Acta Sedimentologica Sinica 21, 461-466.

Li, T., Liu, Z., Hall, M., Berne, S., Saito, Y., Cang, S., Cheng, Z., 2001. Heinrich event imprints in the Okinawa Trough: evidence from oxygen isotope and planktonic foraminifera. Paleogeography Paleoclimatology Paleoecology 176, 133-146.

Liu, Z., Li T., Li P., Huang, Q., Cheng, Z., Wei, G., Liu L., Li, Z., Berne, S., Saito, Y., 2001. The 

Bulletin 46, 153-157.

Milliman, J. D., Meade, R.C., 1983. World-wide delivery of river sediment to oceans. Journal of Geology 91, 1-21.

Mix, A.C., Bard, E., Schneider, R., 2001. Environmental processes of the ice age: land, ocean, glaciers (EPILOG). Quaternary Science Reviews 20, 627-657.

Müller P.J., Kirst G., Ruhland G., Storch, I.V., Melé, A.R., 1998. Calibration of the alkenone paleotemperature index $\mathrm{U}_{37}{ }^{\mathrm{k}}$ based on core-top from the eastern South Atlantic and the global ocean $\left(60^{\circ} \mathrm{N} 60^{\circ} \mathrm{S}\right)$. Geochimica et Cosmochimica Acta 62, 1757-1772.

Nakano, H., Tsujino, H., Furue, R., 2008. The Kuroshio Current system as a jet and twin “relative” recirculation gyres embedded in the Sverdrup circulation. Dynamics of

Prahl, F.G., Wakeham, S.G, 1987. Calibration of unsaturation patterns in long-chain ketone

541 Qiao, F., Yang, Y., Lv, X., Xia, C., Chen, X., Wang, B., Yuan, Y., 2006. Coastal upwelling in the 
East China Sea in winter. Journal of Geophysical Research 111, doi:10.1029/2005JC003264.

Qin, Y., Zhao, Y., Chen, L., Zhao, S., (ed) 1987. Geology of the East China Sea (in Chinese). Beijing, Science Press, P6.

Qiu, B., Lukas, R., 1996. Seasonal and interannual variability of the North Equatorial Current, the Mindanao Current, and the Kuroshio along the Pacific western boundary. Journal of Geophysical Research 101, 12315-12330.

Qu, T., Lukas, R., 2003. The bifurcation of the North Equatorial Current in the Pacific. Journal of Physical Oceanography 33, 5-18.

Roemmich, D., McCallister, T., 1989. Large scale circulation of the North Pacific Ocean. Progress in Oceanography 22, 171-204.

Schmidt, M.W., Vautravers, M.J., Spero, H.J., 2006. Rapid subtropical North Atlantic salinity oscillations across Dansgaard-Oeschger cycle. Nature 443, 561-564.

Shi, Y., Yu, G., 2003. Warm-humid climate and transgressions during 40 30 ka B.P. and their potential mechanisms (in Chinese with English abstract). Quaternary Sciences 23, 1-11.

Shinjo, R., Ban, M., Saito, K., Kato, Y., 1991. K-Ar dating of the volcanic rocks in the Ryukyu arc (in Japanese, with English abstract). J. Jpn. Assoc. Miner. Petrol. Econ. Geol. 86, 323-328.

Sibuet, J. C., Deffontaines, B., Hsu, S. K., Thareau, N., Formal J. P. L., Liu, C. S., ACT party, 1998. Okinawa trough backarc basin: Early tectonic and magmatic evolution. Journal of Geophysical Research 103, B12, 30,245- 30,267. 
Stuiver, M., Reimer, P.J., Braziunas, T.F., 1998. High-precision radiocarbon age calibration for terrestrial and marine samples. Radiocarbon 40, 1127-1151.

Sun, Y.B., Oppo, D.W., Xiang, R., Liu, W., Gao, S., 2005. Last deglaciation in the Okinawa Trough: Subtropical northwest Pacific link to Northern Hemisphere and tropical climate. Paleoceanography 20, A4005. doi:10.1029/2004PA001061.

Tanaka, Y., 2003. Coccolith flux and species assemblages at the shelf edge and in the Okinawa Trough of the East China Sea. Deep-Sea Research II: Topical Studies in Oceanography 50, 503-511.

Toledo, F.A.L., Costa, K.B., Pivel, M.A.G., 2007. Salinity changes in the western tropical South Atlantic during the last 30 kyr. Global and Planetary Changes 57, 383-395.

Tseng C., Lin C., Chen S., Shyu C., 2000. Temporal and spatial variations of sea surface temperature in the East China Sea. Continental Shelf Research 20. 373-387.

Ujiié, H., Ujiié, Y., 1999. Late Quaternary course changes of the kuroshio Current in the Ryukyu Arc region, northwestern Pacific Ocean. Marine Micropaleontoloty 37, 23-40.

Ujiié, Y., Ujiié, H., Taira, A., Nakamura, T., Oguri, K., 2003. Spatial and temporal variability of surface water in the Kuroshio source region, Pacific Ocean, over the past 21, 000 years: evidence from planktonic foraminifera. Marine Micropaleontoloty 49, 335-364.

Villanueva, J., Pelejero, C., Grimalt, J. O., 1997. Clean up procedures for the unbiased estimation of $\mathrm{C}_{37}$ alkenone sea surface temperatures and terregenous n-alkane inputs in paleoceanography. Journal of Chromatography 757, 145-151.

Waelbroeck, C., Labeyrie, L., Michel, E., Duplessy, J.C., McManus, J.F., Lambeck, K., Balbon, 
E., Labracherie, M., 2002. Sea-level and deep water temperature changes derived from benthic foraminifera isotopic records. Quaternary Science Reviews 21, 295-305.

Wang Y.J., Cheng H., Edwards, R.L., An Z.S. Wu J.Y., Shen, C.C., Dorale, J.A., 2001. A high-resolution absolute-dated late Pleistocene monsoon record from Hulu Cave, China. Science 294, 2345-2348.

Wang, P., Sun, X., 1994. Last glacial maximum in China: comparison between land and sea. Catena, 23, 341-353.

Wang, Q., Hu, D., 2006. Bifurcation of the North Equatorial Current derived from altimetry in the Pacific Ocean. Journal of Hydrodynamics 18, 620-626.

Wanner, H., Beer, J., Bütikofer, J., Crowley, T.J., Cubasch, U., Flückiger, J., Goosse, H., Grosjean, M., Joos, F., Kaplan, J.O., Küttel, M., Müller, S.A., Prentice, I.C., Solomina, O., Stocker, T.F., Tarasov, P., Wagner, M., Widmann, M., 2008. Mid- to Late Holocene climate change: an overview. Quaternary Science Reviews 27, 1791-1828.

Weldeab, S., Schneider, R.R., Kölling, M., 2006. Deglacial sea surface temperature and salinity increase in the western tropical Atlantic in synchrony with high latitude climate instabilities. Earth and Planetary Science Letters 241, 699-706.

Wellner, R.W., Bartek, L.R., 2003. The effect of sea level, climate, and shelf physiography on the development of incised-valley complexes: a modern example from the East China Sea. Journal of sedimentary research 73, 926-940.

Wyrtki, K., 1975. El Niño- the dynamic response of the Pacific Ocean to atmospheric forcing. Journal of Physical Oceanography 5, 572-584. 
605 Xiong, Y., Liu, Z., 2004. The late Quaternary resource variation and its cause of the middle

606 Okinawa trough (in Chinese with English abstract). Acta Oceanologica Sinica 26, 61-71.

607 Xu, X., Yamasaki, M., Oda, M., Honda, M.C., 2005. Comparison of seasonal flux variations of 608 planktonic foraminifera in sediment traps on both sides of the Ryukyu Islands, Japan. $609 \quad$ Marine Micropaleontology 58, 45-55.

610 Xu, X., Oda, M., 1999. Surface-water evolution of the eastern East China Sea during the last 36, 000 years. Marine Geology 156, 285-304.

Yamasaki M., Oda M., 2003. Sedimentation of planktonic foraminifera in the East China Sea: evidence from a sediment trap experiment. Marine Micropaleontology 49, 3-20.

Yang, D., Chen, K., Shu, X., 2004. A preliminary study on the paleoenvironment during MIS 3 in the Changjiang delta region (in Chinese with English abstract). Quaternary Sciences 24, 525-530. Glacial Maximum from observed sea-level minima. Nature 406, 713-716. cooling event in the middle Okinawa Trough. Geo-marine Letters 28(3), 131-136.

621 Yuan, D., Cheng, H., Edwards, R.L., Dykoski, C.A., Kelly, M.J., Zhang, M., Qing, J., Lin, Y., Wang, Y., Wu, J., Dorale, J.A., An, Z., Cai, Y., 2004. Timing, duration, and transitions of the last interglacial Asian Monsoon. Science 304, 575-578. Estuarine, Coastal and Shelf Science 41, 631-658. 
626 Zhang, J., Letolle, R., Martin, J.M., Jusserand, C., Mouchel, J.M., 1990. Stable oxygen isotope

627 distribution in the Huanghe (Yellow River) and the Changjiang (Yangtze River) estuarine $628 \quad$ systems. Continental Shelf Research 10, 369-384.

629 Zhao, B., Wang, Z., Chen, J., Chen, Z., 2008. Marine sediment records and relative sea level

630 change during late Pleistocene in the Changjiang delta area and adjacent continental shelf.

631 Quaternary International 186, 164-172.

632 Zhou, H., Li, T., Jia, G., Zhu, Z., Chi, B., Cao, Q., Sun, R., Peng, P., 2007. Sea surface

633 temperature reconstruction for the middle Okinawa Trough during the last

634 glacial-interglacial cycle using $\mathrm{C}_{37}$ unsaturated alkenones. Palaeogeography, Palaeoclimatology, Palaeoecology 246, 440-453. 
636 Section 2: table caption

637 Table 1 AMS ${ }^{14} \mathrm{C}$ ages measured in core DGKS9604

638

639

Table $2 \delta^{18} \mathrm{O}$ and SST records of core DGKS9604

640

641

Table 3 Measured temperature and salinity of different seasons and annual average in study

642 area around $28^{\circ} \mathrm{N}, 127^{\circ} \mathrm{E}$ (data obtained from Japan Oceanographic Data Center database,

643 http://www.jodc.go.jp)

644 
644 Section 3: figure caption

645 Fig. 1 Regional map of the East China Sea and the Okinawa Trough. Location of core 646 DGKS9604 is represented by black bold circle. Reference cores, DGKS9603 (Liu et al., 2001), 647 Z $Z_{14-6}$ (Zhou et al., 2007), MD982195 (Ijiri et al., 2005), A7 (Sun et al., 2005) are represented by 648 gray bold circles. Shaded arrows represent the Kuroshio Current and its branches, small and 649 white arrows show fresh water discharge from the Chinese continent (after Xu et al., 2005). 650 SYD- Suao-Yonaguni Depression, TS - Tokara Strait.

651

652 Fig. 2 Lithology and chronology of core DGKS9604. Number beside hollow triangle

653 represents calibrated AMS ${ }^{14} \mathrm{C}$ ages with one-sigma range in parentheses. Sedimentation rates are 654 also shown.

655

656

Fig. 3 A typical gas chromatogram showing the separation and retention times of alkanes

657 and alkenones for a sample from the Holocene of core DGKS9604. $\mathrm{C}_{25}-\mathrm{C}_{33}$ represent long-chain

658 alkane peaks, $\mathrm{C}_{37: 2 \mathrm{Me}}$ and $\mathrm{C}_{37: 3 \mathrm{Me}}$ present the peaks for $\mathrm{C}_{37: 2}$ and $\mathrm{C}_{37: 3}$ alkenones. The $\mathrm{C}_{38}$ 659 alkenone peaks are also shown here.

660

661 Fig. 4 Linear relationship between SSS and $\delta^{18} \mathrm{O}_{\mathrm{w}}$ in the region from ECS to the coast off 662 the southern Japan influenced by the Kuroshio Current. This plot is drawn based on high 663 accuracy measurements of SSS and $\delta^{18} \mathrm{O}_{\mathrm{w}}$ of seawater from 10 stations (modified after Oba, 664 1990). 
Fig. 5 Comparison of the climate evolution in the middle Okinawa Trough with temperature records from Greenland, Asian summer monsoon intensity and sea level. (A) Sea level rise at the 668 Sunder Shelf, Southeast Asia, in the last deglaciation (Hanebuth et al., 2000; Hanebuth et al., 669 2008); the blue bar depicts MWP-19kyr and MWP-1A. (B) $\delta^{18} \mathrm{O}_{\text {ice }}$ of the GISP2 Greenland ice 670 core (Grootes et al., 1993). (C) Stacked stalagmite $\delta^{18} \mathrm{O}$ from Hulu cave (Wang et al., 2001) and 671 Dongge Cave (Yuan et al., 2004) in which lighter peaks indicating high precipitation. (D) $\delta^{18} \mathrm{O}$ 672 record of G. sacculifer from core DGKS9604. (E) Alkenone-SST record of core DGKS9604. (F) 673 Reconstructed SSS of core DGKS9604. The red line is five-point average and the blue line 674 represents the average SSS value of modern situation around 34.4\%. Climatic intervals are 675 abbreviated as follows: M-LH, Mid-to-late Holocene; EH, early Holocene; LLD, late last 676 deglaciation; ELD, early last deglaciation; FG, full deglaciation; LPG, late pre-glaciation; EPG, 677 early pre-glaciation; YD, Younger Dryas; BA, Bølling-Allerød; H1, Heinrich 1; H2, Heinrich 2; 678 H3, Heinrich3. Numbers depict Dansgaard-Oeschger cycles.

Fig. 6 Comparison of SST records based on different indexes from the middle Okinawa 681 Trough showing consistent warming during late stage of last deglaciation, from 17 to 12 cal kyr 682 BP (shaded area). A) SST estimates for warm (red curve) and cold (black curve) seasons using 683 the modern analog technique (MAT) from core DGKS9603 (Li et al., 2001), B) Mg / Ca SST 684 reconstruction from the core A7 $\left(126^{\circ} 58.7^{\prime} \mathrm{E}, 27^{\circ} 49.2^{\prime} \mathrm{N}\right)$ (Sun et al., 2005), C) alkenone 
685 unsaturation index based SST reconstruction from the core DGKS9604 (green curve) of this 686 study. 